\title{
Epiphytes mediate the trophic role of sea urchins in Thalassia testudinum seagrass beds
}

\author{
Candela Marco-Méndez ${ }^{1, *}$, Patricia Prado ${ }^{2,3}$, Kenneth L. Heck ${ }^{4,5}$, Just Cebrián ${ }^{4,5}$, \\ Jose Luis Sánchez-Lizaso ${ }^{1}$
}

\begin{abstract}
${ }^{1}$ Departamento de Ciencias del Mar y Biología Aplicada, Universidad de Alicante, Apdo. Correos 99, 03080 Alicante, Spain ${ }^{2}$ IRTA - Sant Carles de la Ràpita. Ctra. Poble Nou km 5.5, Aptdo. Correos 200, 43540 Sant Carles de la Ràpita, Tarragona, Spain ${ }^{3}$ Department of Biology, East Carolina University, Greenville, North Carolina 27858, USA

${ }^{4}$ Dauphin Island Sea Laboratory, 101 Bienville Boulevard, Dauphin Island, Alabama 36528, USA

${ }^{5}$ Department of Marine Sciences, University of South Alabama, LSCB 25 Mobile, Alabama 36688-0002, USA
\end{abstract}

\begin{abstract}
The trophic role of the sea urchin Lytechinus variegatus (Lamarck) and the importance of epiphytes as mediators of trophic interactions were evaluated in a Thalassia testudinum meadow, St. Joseph Bay, Florida, in fall 2010. Tethering experiments were deployed within the meadow to assess consumption rates, and food choice experiments, with combinations of different types of $T$. testudinum leaves, green leaves and detached (decayed) leaves, both with and without epiphytes, were carried out with individual urchins in 4 different $24 \mathrm{~h}$ feeding trials. Lytechinus variegatus had higher consumption rates on decayed (12.15 $\pm 1.3 \mathrm{mg} \mathrm{DW} \mathrm{shoot}^{-1} \mathrm{~d}^{-1}$; mean $\pm \mathrm{SE}$ ) compared to an undetectable consumption of green seagrass leaves, and consistently chose epiphytized leaves of both type. Therefore, consumption rates were highest for decayed leaves with epiphytes. This choice may be related to the significantly higher epiphytic biomass on decayed $\left(3.64 \pm 0.28 \mathrm{mg} \mathrm{DW} \mathrm{cm}^{-2}\right)$ than on green leaves $\left(2.11 \pm 0.25 \mathrm{mg} \mathrm{DW} \mathrm{cm}^{-2}\right)$. Stable isotope analyses pointed to epiphytes and green leaves as the main sources of nitrogen and carbon in $L$. variegatus diet. These results suggest that epiphytes mediate trophic interactions between sea urchins and turtlegrass. Therefore, changes in epiphytes and decayed leaf biomass can regulate sea urchin foraging and its impact on the trophic dynamics of the meadows.
\end{abstract}

KEY WORDS: Food choice $\cdot$ Lytechinus variegatus $\cdot$ Thalassia testudinum $\cdot$ Epiphytes $\cdot$ Isotopes

\section{INTRODUCTION}

The role of herbivory in seagrass ecosystems has recently received much attention. Plant availability, nutrient conditions, historical and present harvesting of herbivore populations, recruitment and predation processes, among other factors may interact to influence the abundance of herbivore populations and the consumption of seagrasses (Heck \& Valentine 2006, Prado et al. 2008a, 2009, 2010a). Many studies have reported that $<10 \%$ of the annual aboveground primary productivity (APP) usually enters the food web via grazing in seagrass beds (see review by Cebrián \& Duarte 1998), with the remaining productivity enter- ing the detrital food web through being buried in sediments or exported to other neighboring systems (e.g. Thayer et al. 1984, Zieman \& Zieman 1989). Yet, there is also a growing body of literature documenting the importance of seagrass herbivory in many seagrass systems (see reviews by Heck \& Valentine 2006, Valentine \& Duffy 2006), particularly by macroherbivores, such as fish and sea urchins, that may consume $>50 \%$ of the annual APP (Prado et al. 2007a). Large consumption rates may be a mechanism to compensate for the low nutritional quality of seagrass leaves (Mattson 1980, Goecker et al. 2005), which feature high $\mathrm{C}: \mathrm{N}$ ratios and structural constituents such as cellulose that are not easily digested by many marine 
organisms (Velimirov 1984, Frantzis et al. 1992). It has been suggested that seagrass detritus fraction provides a low-fiber and high-nitrogen food after microbial colonization, which renders it nutritious for animals after the breakdown of tissues and plant chemical defenses (Mann 1972, Robertson et al. 1982). Large numbers of invertebrates, including echinoderms, amphipods, and isopods, feed on decaying leaves and organic matter from seagrass beds (Fenchel 1970, Robertson et al. 1982). Abundant sea urchins in seagrass ecosystems, such as Lytechinus variegatus (Camp et al. 1973, Heck \& Valentine 1995, Valentine \& Heck 1999) are generalist consumers and feed both on live and dead seagrass leaves (Beddingfield \& McClintock 2000, Watts et al. 2007). Therefore, the relative availability of green and decaying leaves, as well as the herbivore's choice of leaf type, may be important factors determining sea urchin effects within seagrass meadows. This issue has been inadequately investigated, although it can have important consequences for the functioning of ecosystems, depending on the different interactions between grazers and seasonal changes in the standing plant biomass, production (Duarte 1989, Kaldy \& Dunton 2000), and leaf loss dynamics (Francour 1990, Romero et al. 1992). Previous studies have suggested that sea urchins preferentially feed on epiphytes (Verlaque \& Nédelec 1983, Shepherd 1987, Tomas et al. 2005a, Vergés et al. 2011), possibly due to their C:N ratios and the absence of refractory plant material. Also, the composition of the epiphyte assemblage may influence consumption through changes in the abundance of certain species or morphological groups (Gacia et al. 1999, Thacker et al. 2001, Prado et al. 2007b, 2008b).

The multiplicity of factors involved in seagrass trophic interactions requires the use of analytical and manipulative methods that integrate temporal variability in resource acquisition. Stable isotope analyses have been useful in providing integrative information on the relative importance of dietary sources (e.g. Tomas et al. 2006, Prado et al. 2010a), but they may not identify minor trophic resources and deviations from conventional values of fractionation due to variability in taxonomic level, individual age, and type of N excretion (see review by Vanderklift \& Ponsard 2003, Crawley et al. 2007). In addition, contributions from diet sources with similar isotopic signatures (e.g. epiphytes or macroalgae) may be difficult to distinguish and quantify. Therefore, other methods, such as analyses of stomach contents, provide complementary information to test and validate the results of stable isotope models (e.g. Harrigan et al. 1989, Cocheret de la Morinière et al. 2003). Addi- tional knowledge obtained from measurements of consumption rates of the different food sources is also central to the complete understanding of fluxes of energy and matter to higher trophic levels (Fry et al. 1984, Lepoint et al. 2000), as well as growth patterns of populations. However, consumption rates are often assessed using indirect methods, such as quantification of herbivore bite marks, which tend to underestimate seagrass consumption (e.g. Cebrián et al. 1996) compared to less frequently-used direct methods such as tethering experiments (e.g. Kirsch et al. 2002, Tomas et al. 2005b, Prado et al. 2007a).

In the eastern Gulf of Mexico, seagrass beds are typically dominated by Thalassia testudinum (Zieman \& Zieman 1989), and the sea urchin Lytechinus variegatus is the main herbivore species, particularly within the northern region (Camp et al. 1973, Greenway 1976, Macia \& Lirman 1999). However, L. variegatus has also been reported to ingest decaying leaf material, at even higher rates than green leaves (Montague et al. 1991). In addition, epiphytized leaves may be preferred over non-epiphytized leaves (Greenway 1995). In this study we aimed to evaluate consumption of detrital vs. green leaves of $T$. testudinum and to elucidate the role of epiphytes in mediating sea urchin consumption in the northeastern Gulf of Mexico. Preliminary feeding observations conducted by randomly collecting sea urchins ( $\mathrm{n}=$ 40) within the seagrass bed pointed to ca. 5 times more individuals feeding on detrital material than on green leaves, and we hypothesized that consumption rates would also reflect this pattern. More specifically, we assessed (1) consumption rates of green and detrital leaves (mg DW shoot ${ }^{-1}$ day $^{-1}$ ) of T. testudinum using tethering experiments; and (2) the influence of decomposition and epiphytes in sea urchin preferences, using paired combinations of green and decaying seagrass leaves with and without epiphytes. In addition, nutrient contents in seagrass and epiphytes, as well as epiphyte biomass and composition, were investigated as potentially explanatory variables, and gut contents and stable isotope analyses were used to measure the relative importance of seagrass and epiphytes in sea urchin diets and to assess dietary contributions in the longer term.

\section{MATERIALS AND METHODS}

\section{Study site}

The study site was located at the T.H. Stone Memorial Park in St. Joseph Bay, Florida, in the northeast 
Gulf of Mexico. We selected this location because of low human impact and low nutrient conditions, and because it offered easy access to lush seagrass meadows with high sea urchin abundance. Salinity typically ranges from 30 to 36\% (Stewart \& Gorsline 1962, Folger 1972), and seagrass species composition is dominated by turtlegrass Thalassia testudinum, with lesser amounts of manatee grass Syringodium filiforme and shoal grass Halodule wrightii (Iverson \& Bittaker, 1986). Seagrass productivity is highly seasonal, with leaf biomass and density peaking near $150 \mathrm{~g} \mathrm{AFDW} \mathrm{m}^{-2}$ and 3000 leaves $\mathrm{m}^{-2}$ from June through August (Iverson \& Bittaker 1986). Our work was conducted in October 2010, and sea urchin abundance in the area was $8.8 \pm 1.7$ ind. $\mathrm{m}^{-2}$, green leaves shoot density was $637.78 \pm 25.25$ shoots $\mathrm{m}^{-2}$, and seagrass cover was $81.17 \pm 2.71 \%$. Biomass of decayed leaves was $44.9 \pm 6.4 \mathrm{~g} \mathrm{DW} \mathrm{m}^{-2}$ and of green leaves was ca. $33.7 \pm 4.1 \mathrm{~g} \mathrm{DW} \mathrm{m}^{-2}$. All results are mean $\pm \mathrm{SE}$, if not stated otherwise.

\section{Tethering experiments}

The consumption rates of green and decayed Thalassia testudinum leaves were estimated in 2 separated tethering experiments. Each replicate $(\mathrm{n}=20)$ included 3 leaves from which previous bite marks were removed with scissors. We measured the leaf area (length and width) and hole-punched all the shoots at the base of the leaves to control for growth rates of tethers during the experimental period (Prado et al. 2007a). Green and decayed leaves were attached to pickets and deployed haphazardly within the turtlegrass bed. After $4 \mathrm{~d}$, all the leaves were collected and measured again for variation in length and width whenever a grazing bite mark was present. Additionally, we collected 25 green and 25 decayed leaves, removed epiphytes with a razor blade and dried them to a constant weight at $60^{\circ} \mathrm{C}$ for $24 \mathrm{~h}$ to assess area-DW relationships (Green leaves: $y=$ $0.0054 x-0.0116, \mathrm{R}^{2}=0.76, \mathrm{df}=24, \quad F=73.35$; Decayed leaves: $y=0.0038 x+0.0071, \mathrm{R}^{2}=0.65$, $\mathrm{df}=$ $24, F=44.42$ ), and we expressed consumption rates as mg DW d $\mathrm{d}^{-1}$ lost to sea urchins.

\section{Food choice experiments}

Food choice experiments were used to test the effect of leaf type (green vs. decayed) and epiphytes (present vs. absent) on consumption rates of Lytechinus variegatus (expressed as leaf area loss in $\mathrm{cm}^{2}$ ) by exposing in- dividuals to 4 different experiments based on specific paired combinations of food resources ( $n=18$ paired replicates in each of the 4 food choice experiments): (1) Decayed non-epiphytized vs. green non-epiphytized (DNE vs. GNE); (2) green epiphytized vs. green nonepiphytized (GE vs. GNE); (3) decayed epiphytized vs. decayed non-epiphytized (DE vs. DNE); and (4) green epiphytized vs. decayed epiphytized (GE vs DE). All the experiments were carried out in six $50 \times 50 \mathrm{~cm}^{2}$ cages, made of PVC and plastic mesh (each containing 4 sea urchins and 3 replicate shoots, with the same area, of the different paired combinations) haphazardly deployed on an unvegetated bottom adjacent to the shallow study bed (ca. $1 \mathrm{~m}$ depth). In each experiment, replicates $(n=18)$ were paired shoots, each comprised of 3 leaves (an average of: $41.38 \pm 1.24 \mathrm{~cm}^{2}$ ) of a paired combination of choices (e.g. decayed or green leaves, epiphytized or non-epiphytized). Previous bite marks were removed with scissors and all the replicates were previously measured and hole-punched to control for growth that might occur during the experimental period (Prado et al. 2007a). All L. variegatus used in this study were mature individuals (i.e. size $>30 \mathrm{~mm}$; Serafy 1979) of $\sim 50 \mathrm{~mm}$ test diameter. After each $24 \mathrm{~h}$ experiment, samples were collected for areal loss measurements and sea urchins replaced with new ones from the surrounding bed.

\section{Gut contents and stable isotope analyses}

To confirm patterns from food choice experiments, 12 sea urchins were randomly collected from the seagrass bed and their gut contents and stable isotope signatures determined. In the laboratory, the muscle of the Aristotle's lantern and gut contents were extracted. Stomach contents were separated by leaf types (green and decayed leaves) under the microscope and then each portion was dried at $60^{\circ} \mathrm{C}$ to a constant weight. The contribution of each leaf type was expressed as a percentage of total food content within the gut.

Shoots of Thalassia testudinum and decayed leaves were randomly collected for nutrient contents $(n=12)$, and stable isotope analyses. The lantern muscle of Lytechinus variegatus $(\mathrm{n}=12)$, green and decayed leaves without epiphytes (GNE and DNE respectively; $\mathrm{n}=6$ of each), and epiphytes of green and decayed leaves (EG and $E D ; n=6$ of each) were dried to a constant weight $\left(60^{\circ} \mathrm{C}, 24 \mathrm{~h}\right)$, and then ground to fine powder for determination of isotopic signatures $\left(\delta^{15} \mathrm{~N}\right.$ and $\delta^{13} \mathrm{C} \%$ ) to identify their corresponding signatures. Analyses were carried out with an EA-IRMS (Thermo 
Finnigan) analyzer in continuous flow configuration. An average difference in isotopic composition between the sample and reference material $\left(\delta_{\text {sample- }}\right.$ standard, expressed as \%o) is determined by the equation:

$$
\left[\left(R_{\text {sample }}-R_{\text {standard }}\right) / R_{\text {standard }}\right] \times 1000=\delta_{\text {sample-standard }}
$$

where $R_{\text {sample }}$ is ${ }^{13} \mathrm{C} /{ }^{12} \mathrm{C}$ or ${ }^{15} \mathrm{~N} /{ }^{14} \mathrm{~N}$ in the sample; $R_{\text {standard }}$ is ${ }^{13} \mathrm{C} /{ }^{12} \mathrm{C}$ or ${ }^{15} \mathrm{~N} /{ }^{14} \mathrm{~N}$ in the working reference $\left(\mathrm{CaCO}_{3}\right.$ from a belemnite [PBD] and atmospheric nitrogen standard for $\delta^{13} \mathrm{C}$ and $\delta^{15} \mathrm{~N}$ measurements, respectively), which is calibrated against an internal standard (i.e. Atropina, IAEA and/or UGS). The analytical precision of the methods used was $0.15 \%$. The analyses were carried out by the Technical Unit of Instrumental Analyses (University of La Coruña).

\section{Nutrient contents in seagrass and epiphytes}

Shoots of Thalassia testudinum and decayed leaves collected for stable isotope analyses were also used for nutrient contents. Analyses were conducted for each type of leaf without epiphytes (GNE and DNE), the epiphytes (from green leaves, EG and from decayed leaves, ED) previously removed from the leaves and, additionally, for green and decayed leaves with epiphytes (GE and DE) to identify nutritional changes between leaf type and by the presence of epiphytes ( $\mathrm{n}=6$ of each). All samples were dry weighed before $\mathrm{N}$ and $\mathrm{C}$ content analyses, as determined by a CarloErba CNH elemental autoanalyzer.

\section{Epiphytic community}

The epiphytic community was investigated on 10 green and decayed leaves collected haphazardly in the meadow $(n=10)$. The oldest leaf of each green shoot was selected as representative of the green shoots' epiphytic and sessile epifaunal assemblages (see Prado et al. 2007b, 2008b), which were scraped from the leaves with a razor blade, and taxa from green and decayed leaves were identified to genus under the microscope. After this, epiphytes were dried to a constant weight $\left(60^{\circ} \mathrm{C}, 24 \mathrm{~h}\right)$, and epiphytic biomass was expressed in $\mathrm{mg} \mathrm{DW} \mathrm{cm}^{-2}$.

\section{Data analyses}

Differences in consumption rates between decayed and green leaves, in the proportion of each leaf type in sea urchin gut and in the number of epiphyte taxa and biomass in each leaf type, were tested with an unpaired $t$-test for independent samples. In all food choice experiments, differences between the different paired samples were investigated with a paired $t$-test for dependent samples.

Differences in the isotope signal $\left(\delta^{15} \mathrm{~N}\right.$ and $\left.\delta^{13} \mathrm{C}\right)$ of green and decayed leaves (without epiphytes) and their respective epiphytes were investigated with a 1-way ANOVA (4 levels). The MixSiR isotope mixing model (Moore \& Semmens 2008) was then used to identify the contributions of green, decayed leaves and epiphytes to sea urchin diet. The input parameters for the model are the isotopic values of consumer and trophic resources (measured in this study) and an overall rate of fractionation with its SE. Usually, this fractionation rate comes from the literature, but since Prado et al. (in press) conducted an experiment with Lytechinus variegatus that specifically aimed at evaluating the effect of diet in isotope fractionation in different tissues (muscle, gonad, gut, and test), we used some of their results to feed the model. Since the tissue investigated in this experiment was muscle, we only used muscle values and not results for the other tissues. In addition, because results by Prado et al. (in press), concluded that there is a strong dietary effect on fractionation (i.e. seagrass, macroalgae, and omnivorous diet fractionations were different) and our urchins were collected where all of those diets were available (seagrass, algal epiphytes, and epifauna), the model was run with a mean fractionation value that was the average of the 3 diets $\left(0.63 \pm 0.29\right.$ for $\delta^{15} \mathrm{~N}$ and $2.49 \pm 0.25$ for $\delta^{13} \mathrm{C}$, means \pm $\mathrm{SE})$. In spite of the limitations, we used these values of fractionation because we are convinced that the mean values are more accurate than assuming the theoretical 3.4\%o enrichment among trophic levels.

A 1-way ANOVA (6 levels) was used to investigate differences in the nutritional content $(\% \mathrm{~N}$ and $\mathrm{C}: \mathrm{N}$ molar ratios) of different food resources available to sea urchins (i.e. each type of leaf material, epiphytized and non-epiphytized, and their respective epiphytes). The Student Newman-Keuls post-hoc test (Zar 1984) was used to investigate the presence of significant groupings. ANOVA assumptions of normality and homogeneity of variance were assessed with the Kolmogorov-Smirnov and Cochran's C-test, respectively. When assumptions could not be met by transformation, the significance level was set at 0.01 to reduce the possibility of a Type I error (Underwood 1997). Significant patterns of variation in epiphytic assemblages were investigated with n-MDS ordination (presence-absence transformation, Bray-Curtis 
index), and the ANOSIM procedure available from the PRIMER 6 software package (Clarke \& Warwick 2001). Finally, SIMPER analyses (Clarke \& Warwick 1994) were used to identify the species that primarily account for observed differences in epiphyte assemblages between green and decayed leaves.

\section{RESULTS}

\section{Tethering experiments}

Lytechinus variegatus showed high consumption rates of decayed leaves $\left(12.1 \pm 1.3 \mathrm{mg}^{\mathrm{DW}}\right.$ shoot $^{-1}$ $\left.\mathrm{d}^{-1}\right)$, whereas consumption of green leaves was undetectable $(t=8.97, \mathrm{df}=38, \mathrm{p}<0.001)$. A slight growth was recorded for green leaves $(0.88 \pm 0.32 \mathrm{mg}$ DW shoot ${ }^{-1} \mathrm{~d}^{-1}$ ) but there was no growth in the decayed leaves during the period of the experiment. Local seagrass biomass during the study period was $33.8 \pm 4.08 \mathrm{~g} \mathrm{DW} \mathrm{m}^{-2}$ of green leaves and $44.9 \pm$ $6.45 \mathrm{~g} \mathrm{DW} \mathrm{m}^{-2}$ of decayed leaves (means $\pm \mathrm{SE}$ ).

\section{Food choice experiments}

No significant differences were observed between consumption of GNE and DNE during the food choice experiments $(t=0.93, \mathrm{df}=17, \mathrm{p}=0.364$, Fig. 1a). In contrast, sea urchins consumed significantly higher amounts of DE than GE $(t=-2.49$, df $=$ 17, p $<0.05$, Fig. 1b), showing that when epiphytes were present sea urchins chose decayed over green leaves. Epiphytized leaves suffered higher consumption than non-epiphytized leaves in the 2 trials where either green or decayed leaves were offered to the sea urchins (DE vs. DNE: $t=8.24, \mathrm{df}=17, \mathrm{p}<0.001$, Fig. $1 \mathrm{c}$; GE vs. GNE: $t=-3.14, \mathrm{df}=17, \mathrm{p}<0.01$, Fig. 1d).

\section{Gut contents and stable isotope analyses}

Fragments of decayed leaves were more abundant than fragments of green leaves $(84.5 \pm 2.9 \%$ vs. $15.4 \pm 2.9 \% ; t=-58.75, \mathrm{df}=22, \mathrm{p}<0.001)$ in the guts of sea urchins.

The $\delta^{15} \mathrm{~N}$ signatures showed significant differences between leaves and epiphytes but not between each type of leaf or epiphytes (1-way ANOVA, p $<0.001$, Fig. 2, Table 1). In contrast, the $\delta^{13} \mathrm{C}$ signatures displayed significant differences between all the samples analysed (1-way ANOVA, $\mathrm{p}<0.001$, Fig. 2, Table 1).

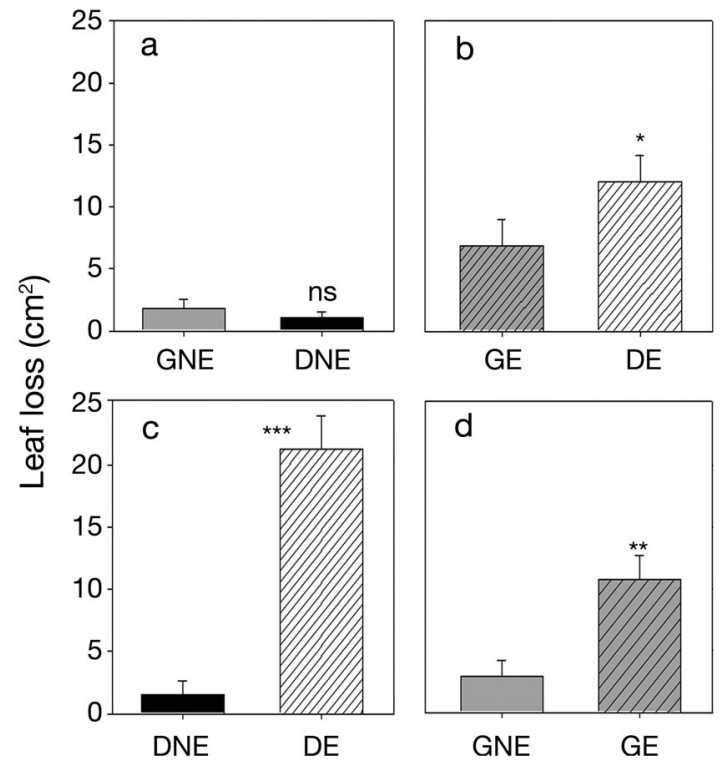

Fig. 1. Leaf loss $\left(\mathrm{cm}^{2}\right)$ to Lytechinus variegatus during paired food choice experiments. (a) Green non-epiphytized leaves (GNE) vs. decayed non-epiphytized leaves (DNE); (b) Green epiphytized leaves (GE) vs. decayed epiphytized leaves (DE); (c) DNE vs. DE; (d) GNE vs. GE. Mean + SE. ${ }^{*} \mathrm{p}<0.05 ;{ }^{* *} \mathrm{p}<$ $0.01{ }^{* * *} \mathrm{p}<0.001 ;$ ns: not significant results

The Aristotle's lantern muscle of Lytechinus variegatus showed a $\delta^{15} \mathrm{~N}$ signature of $8.9 \pm 0.3 \%$ that was close to the epiphyte signal and a $\delta^{13} \mathrm{C}$ signature of $-11.6 \pm$ $0.3 \%$, intermediate to the leaves and the epiphyte signal. Results from MixSir indicated that urchins acquired most of their dietary requirements from epiphytes and a lesser proportion from seagrass leaves. Specifically, the model estimated the contribution of each food source in the sea urchins diet, giving the value at different percentiles. Our results point to epiphytes as the most important food followed by green leaves and decayed leaves (e.g. each of these respective values of contribution, at the percentile $5 \%: 46.8 \%$ of epiphytes, $1.8 \%$ of green leaves and $1 \%$ of decayed leaves; at the percentile 25\%: $55.9 \%, 10.7 \%$ and $5.5 \%$; at the percentile $50 \%: 61 \% .22 \%$ and $13.8 \%$; at the percentile $75 \%: 65.8 \%, 30.5 \%$ and $28.9 \%$, and at the percentile $95 \%$ : $72.9 \%, 39.3 \%$ and $48.3 \%$ ).

\section{Nutrient contents in seagrass leaves and epiphytes}

There were significant differences for both $\% \mathrm{~N}$ and $\mathrm{C}: \mathrm{N}$ molar ratios among the different types of samples analyzed (1-way ANOVA, \%N: df $=5, \mathrm{p}<0.001$; $\mathrm{C}: \mathrm{N}: \mathrm{df}=5, \mathrm{p}<0.001$; Fig. 3). The highest nitrogen content was found in GNE $(2.86 \pm 0.07 \% \mathrm{~N})$, followed by GE $(2.13 \pm 0.12 \% \mathrm{~N})$. All the other sample types 


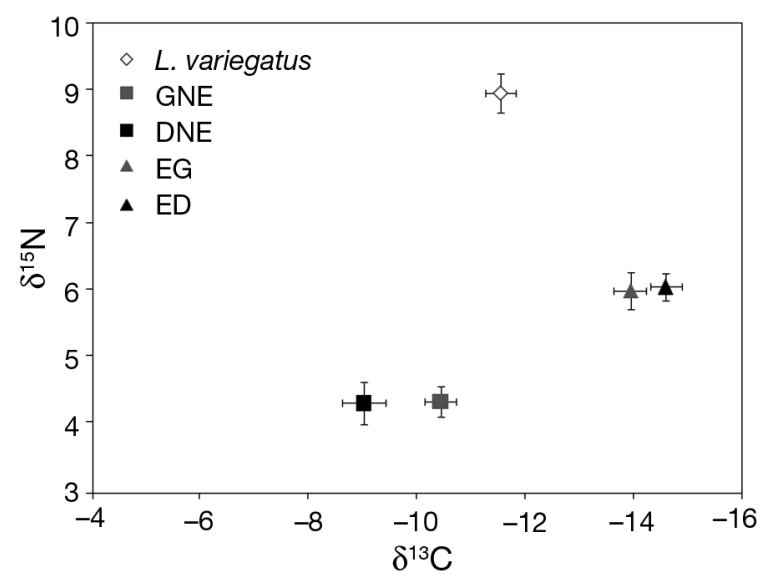

Fig. 2. $\delta^{15} \mathrm{~N}$ and $\delta^{13} \mathrm{C}$ in the Aristotle's lantern muscle of Lytechinus variegatus and in green and decayed non-epiphytized leaves (GNE and DNE, respectively) and their epiphytes (epiphytes of green leaves: EG and epiphytes of decayed leaves: ED)

showed lower values that did not differ significantly from one another (Fig. 3a). Similar but inverse patterns were obtained for $\mathrm{C}: \mathrm{N}$ molar ratios; DNE showed the highest values, followed by DE, ED (epiphytes from decayed leaves), EG (epiphytes from green leaves), GE and GNE (see Fig. 3b).

\section{Epiphytic community}

There were no significant differences in the mean number of epiphytic taxa growing on the leaf surface of green $\left(0.29 \pm 0.03\right.$ taxa $\left.\mathrm{cm}^{-2}\right)$ and decayed leaves $\left(0.28 \pm 0.02\right.$ taxa $\left.\mathrm{cm}^{-2}\right)$ of Thalassia testudinum $(\mathrm{df}=$ $18, t=0.20, \mathrm{p}=0.84)$. In contrast, cover by red calcareous algae was lower on green $(60.3 \pm 4.5 \%)$ than on decayed leaves $(71.8 \pm 2.0 \%)(\mathrm{df}=18, t=2.30, \mathrm{p}=$ $0.03)$. Similarly, epiphytic biomass was higher on decayed $\left(3.6 \pm 0.28 \mathrm{mg} \mathrm{DW} \mathrm{cm}^{-2}\right)$ than on green seagrass leaves $\left(2.1 \pm 0.25 \mathrm{mg} \mathrm{DW} \mathrm{cm}^{-2} ; \mathrm{df}=20, t=\right.$ $-5.16, \mathrm{p}<0.001)$.
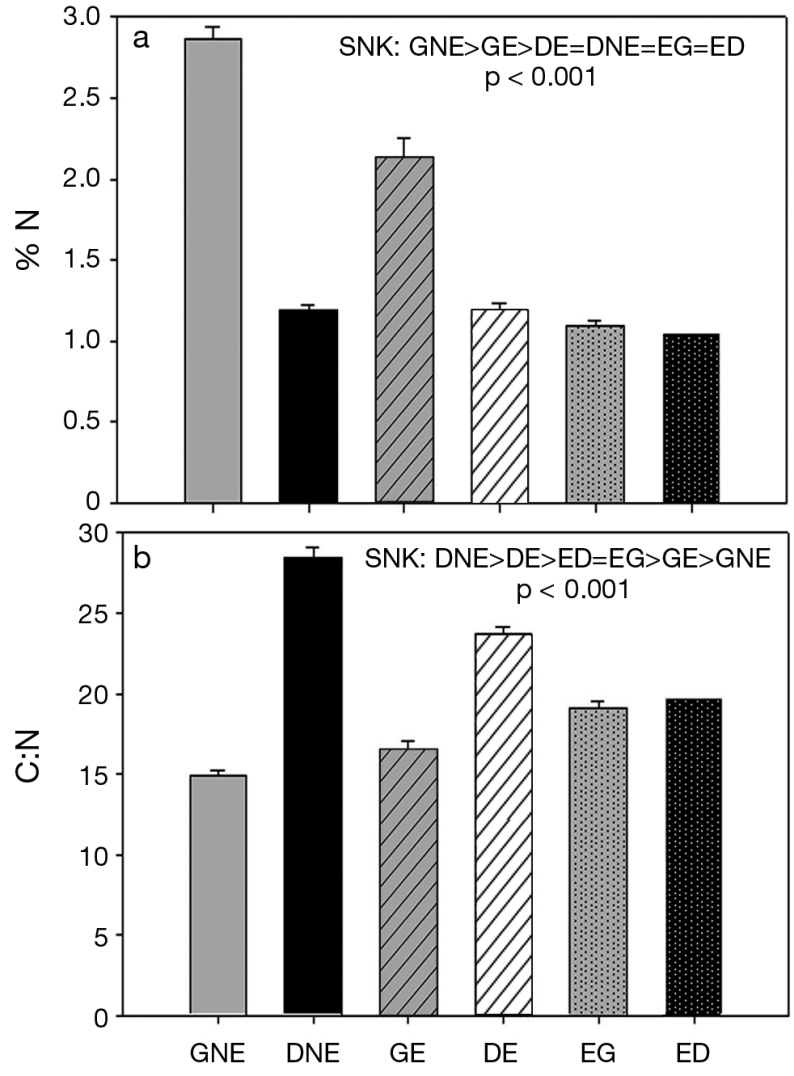

Fig. 3. (a) $\% \mathrm{~N}$ and (b) $\mathrm{C}: \mathrm{N}$ molar ratio in leaves and epiphytes. EG: epiphytes from green leaves; ED: epiphytes from decayed leaves; other labels for leaf and epiphytes as in Fig. 1. Mean + SE

n-MDS ordination of epiphytic taxa, 1-way ANOSIM (Global $R=0.005, p=0.40$ ), and SIMPER analyses (average of dissimilarity: 31.75 ) found no significant differences between green and decayed leaves in the composition of their epiphytic assemblages.

\section{DISCUSSION}

To our knowledge, this is the first time that the consumption of detrital and green leaves has been

Table 1. One-way ANOVA testing for differences on $\delta^{15} \mathrm{~N}$ and $\delta^{13} \mathrm{C}$ between different sample types (non-epiphytized leaves and epiphytes). SNK = significant differences between investigated groups: green non-epiphytized leaves (GNE), decayed non-epiphytized leaves (DNE), epiphytes from green leaves (EG) and epiphytes from decayed leaves (ED) are indicated. ${ }^{* * *} \mathrm{p}<0.001$

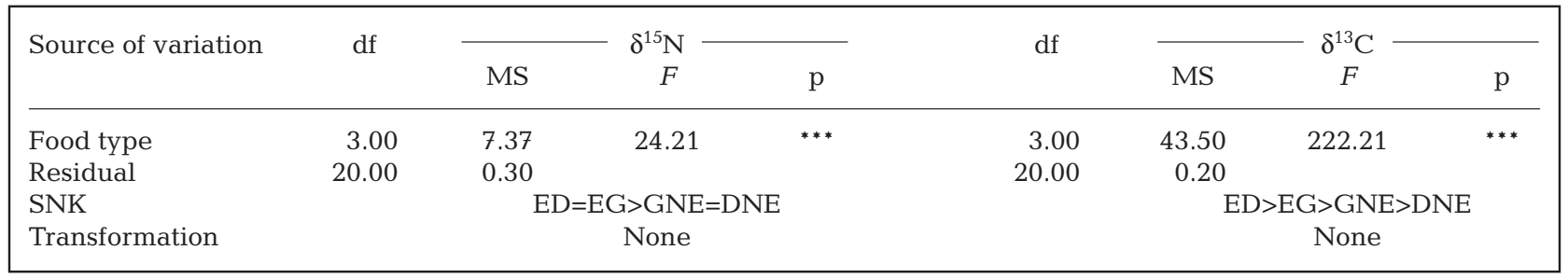


simultaneously compared using tethering experiments. Results showed substantial consumption of detrital leaves, whereas consumption of green leaves was undetectable. Our food-choice experiments demonstrated that these differences in consumption were strongly mediated by epiphytes; detrital leaves were largely preferred over green leaves but only when epiphytes were present (Montague et al. 1991, Greenway 1995). Our results confirm previous evidence that decaying plant material is an important dietary resource for sea urchins (Lowe \& Lawrence 1976, Klumpp \& Van der Valk 1984), and further show that this dietary choice is largely dependent on the presence of epiphytes. Our results also provide new quantitative information on the detritivorous role of Lytechinus variegatus in Thalassia testudinum beds during the fall period. Events of intense herbivory in which $L$. variegatus may remove up to 50 to $90 \%$ of the APP of $T$. testudinum, are not uncommon and may be related to dramatic increases in sea urchin density (Camp et al. 1973, Greenway 1976, Valentine \& Heck 1991, Heck \& Valentine 1995). However, given the importance of detrital resources evidenced in this experiment, part of the large spatial and temporal variability in sea urchin grazing observed to date may be related to differences in the biomass of decaying leaves trapped within meadows.

Results from gut contents of Lytechinus variegatus are consistent with our experiments and show that sea urchins ate more detrital leaves than green leaves. In the fall, the abundance of detrital leaves is typically high and often exceeds the biomass of green leaves (in our case by ca. $25 \%$ ). Decomposition of seagrass leaves is known to cause slight changes in the $\delta^{13} \mathrm{C}$ signature (Zieman et al. 1984, Vizzini et al. 2002). Our stable isotope results also evidenced that green leaves were significantly depleted in $\delta^{13} \mathrm{C}$ compared to decayed leaves (ca. 1.4\%) whereas associated epiphytic communities displayed opposite patterns $(0.7 \%$ lower for communities on decayed leaves). The $\delta^{15} \mathrm{~N}$ signatures, however, showed no effects of decomposition, and significant differences were only evident between seagrass leaves and epiphytes (Tomas et al. 2006, Prado et al. 2010a). Results from the MixSir model indicate that $L$. variegatus diet has a higher nitrogen contribution from epiphytes than from seagrass leaves, with comparatively higher contributions from green leaves than from decayed leaves (see also Tomas et al. 2006 for similar contributions to sea urchin diet). However, results from mixing models need to be interpreted with care. In recent controlled experiments with $L$. variegatus (Prado et al. in press), muscle fractionation of indi- viduals fed on green seagrass leaves was lower than for individuals fed on macroalgae $\left(\Delta^{13} \mathrm{C}=-0.86\right.$ and 0.94 , respectively); and for nitrogen, muscle fractionation was higher for seagrass than for algal diets, suggesting a similar contribution from both sources to the diet (Prado et al. in press).

This apparent discrepancy between gut contents, tethering results, and fractionation-corrected stable isotopes results could be explained by variability in the availability of detrital leaves, green leaves, and epiphytes. Shoot density and standing plant biomass were high $\left(637.78 \pm 25.25\right.$ shoots $\mathrm{m}^{-2}$ and $33.79 \mathrm{~g} \mathrm{DW}$ $\mathrm{m}^{-2}$, means $\pm \mathrm{SE}$ ) at the time of our study, which may favour the trapping and accumulation of decaying leaves shed within the seagrass bed, this is also the period of maximum epiphyte biomass (e.g. Tussenbroek 1995, Cebrián et al. 1997). During winter, however, shoot density typically decreases (Valentine \& Heck 1991), and remaining decaying leaves can be more easily exported to neighbouring systems (Mateo et al. 2006, K. Heck \& P. Prado pers. obs.). The isotopic signatures measured during our experiments integrate items consumed by the urchin during previous seasons. Hence, this seasonality in the type and quantity of dietary availability could explain the apparent discrepancy in our results: tethering and food choice experiments showed higher selection for epiphytized decayed leaves, while isotope results suggested slightly higher contributions of green leaves to diet, compared to decayed leaves. The higher consumption of epiphytized leaves at the time of study may be explained by Lytechinus variegatus using a large proportion of its dietary carbon to build the test (Prado et al. in press), which can be in part provided by calcareous red algae (see James 2000 for species feeding on rhodolith beds).

Differences in the temporal availability of food items can lead to profound dietary changes as has been reported many times (Boudouresque \& Verlaque 2001, Wernberg et al. 2003). The impacts of herbivores on seagrass productivity and on the dynamics of the bed may also be related to the relative availability of green vs. decayed leaves (e.g. Tubbs \& Tubbs 1982, 1983, Prado et al. 2008a). In winter, with less biomass of green and decayed leaves, the impacts of herbivory on the meadow could be greater. Indeed, in previous manipulative experiments, the number of urchins required to completely defoliate a seagrass bed during summer and fall was estimated to be twice that required during the winter period (ca. 40 and 20 ind. $\mathrm{m}^{-2}$; Valentine \& Heck 1991). High abundances of decayed leaves could represent a refugium for green leaves by 
reducing grazing by sea urchins and regulating the nature and magnitude of herbivore impacts on seagrass beds.

Food-choice experiments showed a preference for detrital leaves, but only when epiphytes were present, thus providing another example of the importance of epiphytes in mediating consumption patterns (e.g. Montague et al. 1991, Greenway 1995 Alcoverro et al. 1997, Vergés et al. 2011). Detrital leaves had approximately half the nitrogen content of green leaves alone and a nearly 2-fold higher C:N ratio, but consumption rates of both types of leaves without the epiphytes were not significantly different. Similarly, the urchins consumed decayed leaves with epiphytes to a greater extent than they did green leaves with epiphytes, even though the total nutrient content in leaves and epiphytes was not significantly different. The lack of correlation between the consumption rates and the nutrient content of the diet is also seen in the food-choice experiments when one type of leaf (either green or decayed), with or without epiphytes, was offered to the urchins. This suggests that nutrient content itself did not determine food selectivity by the sea urchins in our study. Chemical and structural defenses in living seagrass tissues also appear to be unimportant for Lytechinus variegatus (see Steele \& Valentine 2010 for evidence of lack of chemical deterrence in this seagrass species). Higher nutrient contents have been repeatedly proposed as a factor triggering preference and consumption of primary producers by herbivores (e.g. McGlathery 1995, Heck et al. 2000, Prado et al. 2010b). However, several authors have found that increased nutrient content in seagrass leaves does not necessarily lead to higher consumption rates by herbivores (for a review see Cebrián 2004).

Our results instead suggest that food selectivity by the sea urchin in this experiment is positively related to the amount of epiphyte biomass. No food preference was exhibited between leaves with no epiphytes. The selection of epiphytized decayed leaves over epiphytized green leaves corresponds to higher epiphyte biomass on the decayed leaves. On average, decayed leaves had $41.6 \%$ more epiphytic biomass and $26.4 \%$ higher cover of red calcareous algae in comparison with green leaves, possibly as a result increased epiphyte accrual on older leaves (Casola et al. 1987, Cebrian et al. 1999), although no differences in epiphyte community composition were found between green and decayed leaves. In addition, when either green or decayed leaves with or without epiphytes were offered to sea urchins, epiphytized leaves were chosen.
To conclude, our results showed that detrital epiphytized leaves were the preferred food item of Lytechinus variegatus and support its detritivorous role within seagrass beds. At other times of the year, field observations (K. Heck \& P. Prado pers. obs.) and long-term stable isotope results suggest that herbivory on green leaves is greater when the abundance of decayed leaves is low. Our results suggest that sea urchins select the highest possible values of epiphyte biomass, which tend to be higher in decayed leaves. In turn, this selection could reduce the impact of the urchin on photosynthetically active green leaves (Valentine \& Heck 1991) and substantially modify the magnitude of top-down effects within meadows. At the ecosystem level, this facultative trophic behaviour of $L$. variegatus may also speed up the recycling of detritus during the fall by enhancing turnover rates of carbon and nitrogen and making them available for plant growth (Cebrián \& Duarte 1995). In addition, by enhancing fragmentation of detrital leaves, urchins may favour the export of carbon and nutrients contained in the detrital fragments to less productive systems such as adjacent beaches and other unvegetated habitats (Wernberg et al. 2005).

Acknowledgements. This study was carried out during a short stay at the Dauphin Island Sea Lab in a collaboration agreement with the University of Alicante, which financed travel costs, sampling and analysis. Thanks to the scientific and technical team of the DISL and to the St. Joe Preserve management staff for hosting us and providing working space.

\section{LITERATURE CITED}

Alcoverro T, Duarte CM, Romero J (1997) The influence of herbivores on Posidonia oceanica epiphytes. Aquat Bot 56:93-104

Beddingfield SD, McClintock JB (2000) Demographic characteristics of Lytechinus variegatus (Echinoidea: Echinodermata) from three habitats in a north Florida bay, Gulf of Mexico. PSZNI: Mar Ecol 21:17-40

Boudouresque CF, Verlaque M (2001) Ecology of Paracentrotus lividus. Dev Aquacult Fish Sci 32:177-216

Camp D, Cobb S, Van Breedfield J (1973) Overgrazing of seagrasses by the regular urchin, Lytechinus variegatus. Bioscience 23:37-38

> Casola E, Scardi M, Mazzella L, Fresi E (1987) Structure of the epiphytic community of Posidonia oceanica leaves in a shallow meadow. PSZNI: Mar Ecol 8:285-296

Cebrián J (2004) Grazing on benthic primary producers. In: Lielsen SL, Banta GT, Pederson MF (eds) Estuarine nutrient cycling: the influence of primary producers. Kluwer Academic, Dordrecht p 153-185

Cebrián J, Duarte CM (1995) Plant growth-rate dependence of detrital carbon storage in ecosystems. Science 268: 1606-1608

- Cebrián J, Duarte CM (1998) Patterns in leaf herbivory on seagrasses. Aquat Bot 60:67-82 
Cebrián J, Duarte CM, Marbà N, Enríquez S, Gallegos M, Olesen B (1996) Herbivory on Posidonia oceanica: magnitude and variability in the Spanish Mediterranean. Mar Ecol Prog Ser 130:147-155

Cebrián J, Duarte CM, Marbà N, Enríquez S (1997) The magnitude and fate of production of four co-occurring Western Mediterranean seagrass species. Mar Ecol Prog Ser 155:29-44

Cebrián J, Enriquez S, Fortes M, Agawin N, Vermaat JE, Duarte CM (1999) Epiphyte accrual on Posidonia oceanica (L.) Delile leaves: implications for light absorption. Bot Mar 42:123-128

Clarke KR, Warwick RM (1994) Change in marine communities: an approach to statistical analysis and interpretation. Plymouth Marine Laboratory, Plymouth

Clarke KR, Warwick RM (2001) Changes in marine communities: an approach to statistical analysis and interpretation. In: PRIMER-E, 2nd edn. PRIMER-E, Plymouth

Cocheret de la Morinière E, Pollux BJA, Nagelkerken I, Hemminga MA, Huiskes AHL, Van Der Velde G (2003) Ontogenetic dietary changes of coral reef fishes in the mangrove-seagrass-reef continuum: stable isotopes and gut-content analysis. Mar Ecol Prog Ser 246:279-289

Crawley KR, Hyndes GA, Vanderklift MA (2007) Variation among diets in discrimination of $\delta^{13} \mathrm{C}$ and $\delta^{15} \mathrm{~N}$ in the amphipod Allorchestes compressa. J Exp Mar Biol Ecol 349:370-377

Duarte CM (1989) Temporal biomass variability and production/biomass relationships of seagrass communities. Mar Ecol Prog Ser 51:269-276

Fenchel T (1970) Studies on the decomposition of organic detritus derived from the turtlegrass Thalassia testudinum. Limnol Oceanogr 15:14-20

Folger DW (1972) Characteristics of estuarine sediments of the United States. US Geol Surv Prof Pap 742:1-95

Francour P (1990) Dynamique de l'écosystème à Posidonia oceanica dans le parc national de Port-Cros: analyse des compartiments matte, litière, faune vagile, échinodermes et poissons. PhD dissertation, Université de P.M Curie, Paris

Frantzis A, Grémare A, Vétion G (1992) Growth rates and RNA: DNA ratios in Paracentrotus lividus (Echinodermata: Echinoidea) fed on benthic macrophytes. J Exp Mar Biol Ecol 156:125-138

Fry B, Andersen RK, Entzeroth L, Bird JL, Parker PL (1984) ${ }^{13} \mathrm{C}$ enrichment and oceanic food web structure in the northwestern Gulf of Mexico. Contrib Mar Sci 27:49-63

Gacia E, Littler MM, Littler DS (1999) An experimental test of the capacity of food web interactions (fish-epiphytesseagrasses) to offset the negative consequences of eutrophication on seagrass communities. Estuar Coast Shelf Sci 48:757-766

Goecker ME, Heck KL, Valentine JF (2005) Effects of nitrogen concentrations in turtlegrass Thalassia testudinum on consumption by the bucktooth parrotfish Sparisoma radians. Mar Ecol Prog Ser 286:239-248

Greenway M (1976) The grazing of Thalassia testudinum in Kingston Harbour, Jamaica. Aquat Bot 2:117-126

Greenway M (1995) Trophic relationships of macrofauna within a Jamaican seagrass meadow and the role of the echinoid Lytechinus variegatus (Lamarck). Bull Mar Sci 56:719-736

Harrigan P, Zieman JC, Macko SA (1989) The base of nutritional support for the gray snapper (Lutjanus griseus): an evaluation based on a combined stomach content and stable isotope analysis. Bull Mar Sci 44:65-77

- Heck KL Jr, Valentine JF (1995) Sea urchin herbivory: evi- dence for long-lasting effects in subtropical seagrass meadows. J Exp Mar Biol Ecol 189:205-217

Heck KL Jr, Valentine JF (2006) Plant-herbivore interactions in seagrass meadows. J Exp Mar Biol Ecol 330: 420-436

Heck KL Jr, Pennock JR, Valentine JF, Coen LD, Sklenar SA (2000) Effects of nutrient enrichment and small predator density on seagrass ecosystems: an experimental assessment. Limnol Oceanogr 45:1041-1057

Iverson RL, Bittaker HF (1986) Seagrass distribution and abundance in eastern Gulf of Mexico coastal waters. Estuar Coast Shelf Sci 22:577-602

James DW (2000) Diet, movement, and covering behavior of the sea urchin Toxopneustes roseus in rhodolith beds in the Gulf of California, Mexico. Mar Biol 137:913-923

Kaldy JE, Dunton KH (2000) Above-and below-ground production, biomass and reproductive ecology of Thalassia testudinum (turtle grass) in a subtropical coastal lagoon. Mar Ecol Prog Ser 193:271-283

> Kirsch KD, Valentine JF, Heck KL (2002) Parrotfish grazing on turtlegrass Thalassia testudinum: evidence for the importance of seagrass consumption in food web dynamics of the Florida Keys National Marine Sanctuary. Mar Ecol Prog Ser 227:71-85

Klumpp DW, Van der Valk A (1984) Nutritional quality of seagrasses Posidonia australis and Heterozostera tasmanica: comparisons between species and stages of decomposition. Mar Biol Lett 5:67-83

Lepoint G, Nyssen F, Gobert S, Dauby P, Bouquegneau JM (2000) Relative impact of a seagrass bed and its adjacent epilithic algal community in consumer diets. Mar Biol 136:513-518

> Lowe EF, Lawrence JM (1976) Absorption efficiencies of Lytechinus variegatus (Lamarck) (Echinodermata: Echinoidea) for selected marine plants. J Exp Mar Biol Ecol 21:223-234

Macia S, Lirman D (1999) Destruction of Florida Bay seagrasses by a grazing front of sea urchins. Bull Mar Sci 65: 593-601

Mann KH (1972) Macrophyte production and detritus food chains in coastal waters. Mem Ist Ital Idrobiol. 29(suppl.): 353-383

Mateo MA, Cebrian J, Dunton K, Mutchler T (2006) Carbon flux in seagrass ecosystems. In: Larkum, WD, Orth RJ, Duarte, CM. (eds) Seagrasses: biology, ecology and conservation. Springer, New York, NY

> Mattson WJ (1980) Herbivory in relation to plant nitrogen content. Annu Rev Ecol Syst 11:119-161

> McGlathery KJ (1995) Nutrient and grazing influences on a subtropical seagrass community. Mar Ecol Prog Ser 122: $239-252$

Montague JR, Aguinaga JA, Ambrisco KL, Vassil DL, Collazo W (1991) Laboratory measurement of ingestion rate for the sea urchin Lytechinus variegatus (Lamarck) (Echinodermata: Echinoidea). Fla Sci 54:129-134

$>$ Moore JW, Semmens BX (2008) Incorporating uncertainly and prior information in stable isotope mixing models. Ecol Lett 11:470-480

> Prado P, Tomas F, Alcoverro T, Romero J (2007a) Extensive direct measurements of Posidonia oceanica defoliation confirm the importance of herbivory in temperate seagrass meadows. Mar Ecol Prog Ser 340:63-71

Prado P, Alcoverro T, Martínez-Crego B, Vergés A, Pérez M, Romero J (2007b) Macrograzers strongly influence patterns of epiphytic assemblages in seagrass meadows. J Exp Mar Biol Ecol 350:130-143

Prado P, Farina S, Tomas F, Romero J, Alcoverro T (2008a) 
Marine protection and meadow size alter fish herbivory in seagrass ecosystems. Mar Ecol Prog Ser 371:11-21

Prado P, Alcoverro T, Romero J (2008b) Seasonal response of Posidonia oceanica epiphytic assemblages to nutrient increase. Mar Ecol Prog Ser 359:89-98

Prado P, Romero J, Alcoverro T (2009) Welcome mats? The role of seagrass meadow structure in controlling postsettlement survival in a keystone sea-urchin species. Estuar Coast Shelf Sci 85:472-478

Prado P, Alcoverro T, Romero J (2010a) Influence of nutrients in the feeding ecology of seagrass (Posidonia oceanica L.) consumers: a stable isotopes approach. Mar Biol 157:715-724

- Prado P, Romero J, Alcoverro T (2010b) Nutrient status, plant availability and seasonal forcing mediate fish herbivory in temperate seagrass beds. Mar Ecol Prog Ser 409:229-239

Prado P, Carmichael RH, Watts SA, Cebrian J, Heck KL Jr (in press) Diet-dependent $\delta^{13} \mathrm{C}$ and $\delta^{15} \mathrm{~N}$ fractionation among sea urchin Lytechinus variegatus tissues: implications for food web models. Mar Ecol Prog Ser

Robertson ML, Mills AL, Zieman JC (1982) Microbial synthesis of detritus-like particulates from dissolved organic carbon released by tropical seagrasses. Mar Ecol Prog Ser 7:279-285

Romero J, Pergent G, Pergent Martini C, Mateo MA, Regnier C (1992) The detritic compartment in a Posidonia oceanica meadow: litter features, decomposition rates, and mineral stocks. PSZNI: Mar Ecol 13:69-83

Serafy K (1979) Echinoids (Echinoidea: Echinodermata). Memoirs of the Hourglass Cruises, Vol 5. Florida Dept of Natural Resources, Marine Research Laboratory, St. Petersburg, FL

Shepherd A (1987) Grazing by the sea urchin Paracentrotus lividus in Posidonia beds at Banyuls, France. In: Boudouresque CF (ed) Colloque International sur Paracentrotus lividus et les oursins comestibles. GIS Posidonie, Marseille, p 83-96

Steele L, Valentine JF (2010) Phenolic content of two subtropical seagrasses affects feeding behavior of mesograzers but not macrograzers. Benthic Ecology Meeting 2010, Wilmington NC (Abstract)

> Stewart RA, Gorsline DS (1962) Recent sedimentary history of St. Joseph's Bay, Florida. Sedimentology 1:256-286

> Thacker R, Ginsburg D, Paul V (2001) Effects of herbivore exclusion and nutrient enrichment on coral reef macroalgae and cyanobacteria. Coral Reefs 19:318-329

Thayer GW, Bjorndal KA, Odgen JC, Williams SL, Zieman JC (1984) Role of larger herbivores in seagrass communities. Estuaries 7:351-376

Tomas F, Turon X, Romero J (2005a) Seasonal and smallscale variability of herbivory pressure on the temperate seagrass Posidonia oceanica (L.). Mar Ecol Prog Ser 301: 95-107

Tomas F, Turon X, Romero J (2005b) Effects of herbivores on a Posidonia oceanica seagrass meadow: importance of epiphytes. Mar Ecol Prog Ser 287:115-125

Tomas F, Álvarez-Cascos D, Turon X, Romero J (2006) Differential element assimilation by sea urchins Paracentrotus lividus in seagrass beds: implications for trophic interaction. Mar Ecol Prog Ser 306:125-131

Tubbs CR, Tubbs JM (1982) Brent geese (Branta bernicla)

Editorial responsibility: Peter Steinberg,

Sydney, New South Wales, Australia and their food in the Solent, southern England. Biol Conserv 23:33-54

Tubbs CR, Tubbs JM (1983) The distribution of Zostera and its exploitation by wildfowl in the Solent, Southern England. Aquat Bot 15:223-239

Tussenbroek BI (1995) Thalassia testudinum leaf dynamics in a Mexican Caribbean coral reef lagoon. Mar Biol 122: $33-40$

Underwood AJ (1997) Experiments in ecology: their logical design and interpretation using analysis of variance. Cambridge University Press, Cambridge

Valentine JF, Duffy JE (2006) The central role of grazing in seagrass ecology. In: Larkum AWD, Orth RJ, Duarte CM (eds) Seagrasses: biology, ecology and their conservation. Kluwer Academic Publishers, Dordrecht, p 463-501

> Valentine JF, Heck KL Jr (1991) The role of sea urchin grazing in regulating subtropical seagrass meadows: evidence from field manipulations in the northern Gulf of Mexico. J Exp Mar Biol Ecol 154:215-230

> Valentine JF, Heck KL Jr (1999) Seagrass herbivory: evidence for the continued grazing of marine grasses. Mar Ecol Prog Ser 176:291-302

- Vanderklift MA, Ponsard S (2003) Sources of variation in consumer-diet ${ }^{15} \mathrm{~N}$ enrichment: a meta-analysis. Oecologia 136:169-182

Velimirov B (1984) Grazing of Sarpa salpa on Posidonia oceanica L. and utilization of its soluble compounds. In: Boudouresque CF, de Grissac AJ, Olivier J (eds) I International Workshop on Posidonia oceanica Beds. GIS Posidonie Publ, Marseille, p 381-387

Vergés A, Alcoverro T, Romero J (2011) Plant defences and the role of epibiosis in mediating within-plant feeding choices of seagrass consumers. Oecologia 166:381-390

Verlaque M, Nédelec H (1983) Biologie de Paracentrotus lividus (Lamarck) sur un substrat rocheux en Corse (Méditerranée, France): alimentation des adultes. Vie Milieu 33:191-201

> Vizzini S, Sar G, Michener RH, Mazzola A (2002) The role and contribution of the seagrass Posidonia oceanica (L.) Delile organic matter for secondary consumers as revealed by carbon and nitrogen stable isotope analysis. Acta Oecol 23:277-285

Watts SA, Powell ML, Lawrence AL, Lawrence JM (2007) Sea urchin culture -emerging species yields roe; supports medical modeling, environmental testing. Glob Aquacul Advocate Jan/Feb p 22-24

> Wernberg T, Kendrick GA, Phillips JC (2003) Regional differences in kelp-associated algal assemblages on temperate limestone reefs in south-western Australia. Divers Distrib 9:427-441

Wernberg T, Kendrick GA, Toohey BD (2005) Modification of the physical environment by an Ecklonia radiata (Laminariales) canopy and implications for associated foliose algae. Aquat Ecol 39:419-430

Zar JH (1984) Biostatistical analysis. Prentice-Hall, Englewood Cliffs, NJ

Zieman JC, Zieman RT (1989). The ecology of the seagrass meadows of the west coast of Florida: a community profile. US Fish Wildl Serv Biol Rep 85 (7.25)

Zieman JC, Iverson RL, Ogden JC (1984) Herbivory effects on Thalassia testudinum leaf growth and nitrogen content. Mar Ecol Prog Ser 15:151-158

Submitted: July 18, 2011; Accepted: April 25, 2012

Proofs received from author(s): July 10, 2012 